\title{
Article
}

\section{The Impact of Geographical Location on the Chemical Compositions of Pimpinella lutea Desf. Growing in Tunisia}

\author{
Hekmat AL-Hmadi ${ }^{1,2}$, Ridha El Mokni ${ }^{3,4}\left(\mathbb{D}\right.$, Rajesh K. Joshi ${ }^{5}$ (D) Mohamed L. Ashour ${ }^{6,7}, *$ (D) \\ and Saoussen Hammami $1, *$ (D)
}

1 Research Unit LR21ES04, Environmental and Clean Processes Chemistry Faculty of Sciences of Monastir, Monastir University, Monastir 5000, Tunisia; hekmat.alhmadi@mu.edu.iq

2 Department of Chemistry, College of Medicine, AL-Muthanna University, Samawah 66001, Iraq

3 Department of Life Sciences, Laboratory of Botany and Plant Ecology, Faculty of Sciences of Bizerta, University of Carthage, Jarzouna 7021, Tunisia; ridhaelmokni@yahoo.fr

4 Department Pharmaceutical Sciences "A", Laboratory of Botany, Cryptogamy and Plant Biology, Faculty of Pharmacy of Monastir, BP 207, Avicenna Street, Monastir 5000 Monastir, Tunisia

5 Department of Natural Product Chemistry, ICMR-National Institute of Traditional Medicine, Nehru Nagar-Belagavi, Karnataka 590010, India; joshirk_natprod@yahoo.com

6 Department of Pharmaceutical Sciences, Pharmacy Program, Batterjee Medical College, P.O. Box 6231, Jeddah 21442, Saudi Arabia

7 Department of Pharmacognosy, Faculty of Pharmacy, Ain Shams University, Cairo 11566, Egypt

* Correspondence: mohamed.ashour@bmc.edu.sa (M.L.A.); h_saoussen@yahoo.fr (S.H.); Tel.: +216-97-291-514 (S.H.)

Citation: AL-Hmadi, H.; El Mokni,

R.; Joshi, R.K.; Ashour, M.L.;

Hammami, S. The Impact of

Geographical Location on the Chemical Compositions of Pimpinella lutea Desf. Growing in Tunisia. Appl. Sci. 2021, 11, 7739. https://doi.org/ 10.3390/app11167739

Academic Editor: Claudio Medana

Received: 29 July 2021

Accepted: 19 August 2021

Published: 23 August 2021

Publisher's Note: MDPI stays neutral with regard to jurisdictional claims in published maps and institutional affiliations.

Copyright: (c) 2021 by the authors. Licensee MDPI, Basel, Switzerland. This article is an open access article distributed under the terms and conditions of the Creative Commons Attribution (CC BY) license (https:/ / creativecommons.org/licenses/by/ $4.0 /)$.

\begin{abstract}
Essential oils are generally produced to confer the protection of medicinal plants against several natural enemies. Variations of chemical and physical environmental factors exert significant influences on plant development. They hence may affect the quality and quantity of volatile organic metabolites of interest and, therefore, the economic applications of essential oils. This research focused on the effects of the harvest region on the production and analytes present in Tunisian Pimpinella lutea Desf. Apiaceae that were collected in three different growing environments (North and South Bizerta and Tabarka). Essential oils extracted from a variety of genotypes were analyzed, for the first time, using gas chromatography and mass spectrometry (GC/FID and GC/MS). The determination of the percentage of essential oil components allowed the recognition of three chemotypes: $\alpha$-transBergamotene quantified at a percentage of $18.1 \%$ in North Bizerta (NBEO), muurola-4,10(14)-dien-1$\beta$-ol identified in South Bizerta (10.1\%, SBEO) and acora-3,7(14)-dien present in a high level of 29.1\% in Tabarka population (TEO). The richness of different populations in sesquiterpenes $(60.2-78.1 \%)$ suggests that Pimpinella lutea Desf. may be used in different industrial segments.
\end{abstract}

Keywords: Pimpinella lutea (Desf.); essential oils; different locations; chemical composition; gas chromatography-mass spectrometry

\section{Introduction}

Up to date, approximately $90 \%$ of Cancer patients are unresponsive to therapy because of multidrug resistance [1]. Consequently, several researchers have renewed their interest in studying the biological activities of medicinal plant extracts and discovering plant-based remedies, including volatile oils [2]. Essential oils are naturally occurring metabolites of high desirability known for their positive effects and beneficial characteristics. They have a long history in inhalation therapies and dermal application by different cultures globally. Their powerful valuable chemicals possess a profound physiological effect, restoring balance and vitality [3]. The use of essential oils obtained from various aromatic plants generally spread worldwide is considered an essential part of the traditional pharmacopeia [4,5]. Presently, essential oils are increasingly crucial in the food and perfume industry, pesticides, and pharmaceutical industries due to their pleasant aroma, diverse 
biological activities, and ease of availability [6-9]. The use of many essential oils as an alternative to synthetic products in destroying bacteria, viruses, and fungi that cause infections, may help avoid toxic side effects in the environment and human health $[10,11]$. Many factors can affect the qualities of essential oils, including the chemotype, chemical composition, biological properties, and yields. Seasonal changes in geographic, environmental, and climatic conditions are among the most prominent factors [12-14].

The oil production also varies depending on different plant species and the extraction method $[15,16]$. The method used to produce an essential oil depends on the type of plant material. True essential oils are extracted through various distillation methods (water and steam distillation). However, some volatile constituents are fragile and susceptible to heat, reactive to moisture during extraction, and difficult to liberate from the surrounding plant material. Thus, other new suitable methods of extraction, such as enfleurage and supercritical carbon dioxide, are utilized to save solvent and energy and extract thermolabile phytocompounds [17]. The crop yields, the chemical compositions, and the physicochemical characteristics determine the usefulness of oil in various applications aside from edible uses, such as in foods, cosmetics, and pharmaceuticals [18]. Many studies have proven that the disparity of locations may affect volatile oils composition and efficiency [19]. Many studied medicinal plants were widely recognized in local herbal medicine as foods and safe medical products [20] due to their wide range of pharmacological uses [21]. A great deal of research has been conducted on the chemical composition and the biological activities of numerous species belonging to the Apiaceae family, including common vegetables (e.g., parsnips, carrots, and celery/celeriac) and condiments (e.g., anise, coriander, chervil, caraway, cumin, dill, and parsley). Pimpinella lutea Desf. Syn. Reutera lutea (Desf.) Maire Figure 1 is known as one of the most excellent flowering Apiaceae plants [22]. It is a perennial plant with fat vertical root; strong principal stem, glabrous, branched at the top, reaching $1.5 \mathrm{~m}$ in height, leaves are pubescent, the lower ones numerous, soft, very large, up to $40 \mathrm{~cm}$ long, pinnate with ovoid or rounded segments, toothed or incised, the others reduced to the sheath or almost, inflorescences in umbel with 3-6 capillary rays. Involucre and involucel almost absent. Petals are yellow rounded at the base, fruits smooth, oval-elongated with prominent ribs [23].

Previous studies conducted on the investigation of the chemical composition of Reutera lutea (Desf.) Maire growing in Algeria led to the isolation of the flavonoid C-glucosides: Isoorientin, isoorientin 6"-O-acetate, and the coumarin: 3,4-dihydro-6,8-dihydroxy-3methylisocoumarin [24]. It has also been demonstrated that the methylene dichloride and butanol extracts are effective corrosion inhibitors for carbon steel in $\mathrm{HCl}$ solution [25]. However, the volatile chemical constituents of Reutera lutea have not yet been identified. Therefore, this is the first study on the hydrodistilled essential oils from the fragrant Pimpinella lutea aerial parts collected from three regions in Tunisia. The main objective is to study its basic properties, the variability in yields and phytochemicals constituting the plant material, and to create awareness and interest in its possible utilization as a source of natural bioactive compounds (Table 1).

Table 1. Characteristics of sampling sites of Pimpinella lutea harvested during the flowering-fruiting period.

\begin{tabular}{ccccc}
\hline Locality & Coordinates & Altitude & Substrate (Soil) & Voucher Specimens \\
\hline $\begin{array}{c}\text { Bizerta North } \\
(\text { Northeast of Tunisia) }\end{array}$ & $\begin{array}{c}\text { Lat. } 37^{\circ} 17^{\prime} 13^{\prime \prime} \mathrm{N} \\
\text { Long. } 09^{\circ} 47^{\prime} 44^{\prime \prime} \mathrm{E}\end{array}$ & 143 & Calcareous marley & $(\mathrm{API} / \mathrm{Reu} . \mathrm{lu} ; 0027 / 2017)$ \\
\hline $\begin{array}{c}\text { Bizerta south } \\
(\text { Northeast of Tunisia) }\end{array}$ & $\begin{array}{c}\text { Lat. } 36^{\circ} 55^{\prime} 14^{\prime \prime} \mathrm{N} \\
\text { Long. } 09^{\circ} 23^{\prime} 40^{\prime \prime} \mathrm{E}\end{array}$ & 417 & Clay-loamy & $(\mathrm{API} / \mathrm{Reu} . \mathrm{lu} ; 0141 / 2017)$ \\
\hline $\begin{array}{c}\text { Tabarka } \\
(\text { Northwest of Tunisia) }\end{array}$ & $\begin{array}{c}\text { Lat. } 36^{\circ} 56^{\prime} 55^{\prime \prime} \mathrm{N} \\
\text { Long. } 08^{\circ} 46^{\prime} 39^{\prime \prime} \mathrm{E}\end{array}$ & 04 & Sandy & $(\mathrm{API} / \mathrm{Reu} . \mathrm{lu} ; 0334 / 2017)$ \\
\hline
\end{tabular}




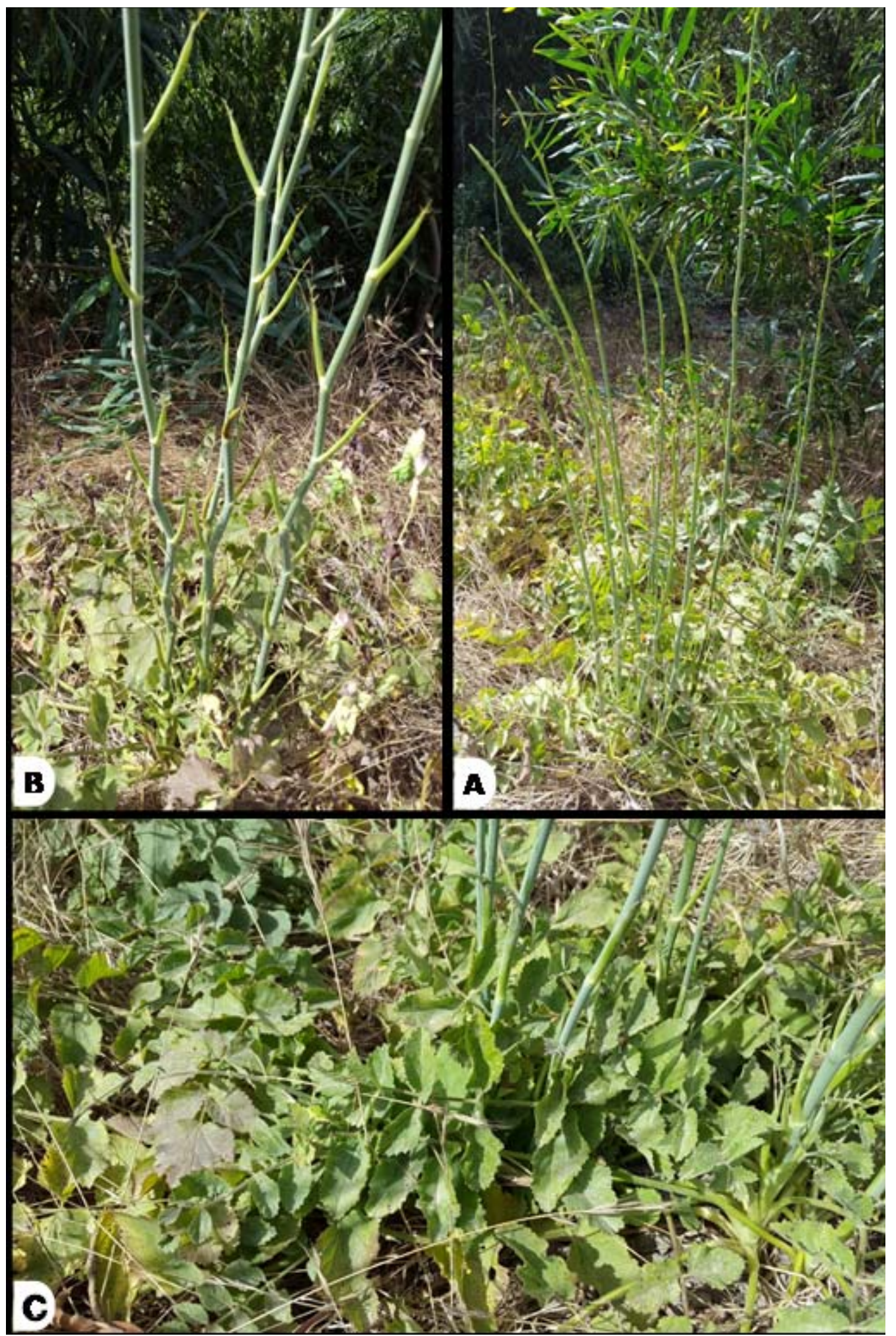

Figure 1. Tunisian Pimpinella lutea Desf. (Tabarka, NW of Tunisia). (A) The habit of the plant in one of its natural habitats; (B) Long, glabrous stems with leaves reduced to sheaths; (C) Basal leaves long, typically pubescent, soft, pinnate with ovoid or rounded segments. (Photographs by Ridha El Mokni). 


\section{Materials and Methods}

\subsection{The Plant Material}

The harvest of Pimpinella lutea aerial parts was done during the flowering-fruiting period from three different geographical areas of Tunisia (North and South Bizerta and Tabarka) (Table 1). The botanical identification of the plant material was carried out and authenticated by Dr. Ridha EL MOKNI affiliated to the Laboratory of Botany, Cryptogamy and Plant Biology, Department of Pharmaceutical Sciences "A", Faculty of Pharmacy, Monastir, Tunisia.

\subsection{Extraction Method}

Air-dried aerial parts of the Pimpinella lutea aromatic plant (100 g of each sample) were extracted via a hydrodistillation process for three hours using a Clevenger-type extractor [26]. The collected essential oils were dehydrated over anhydrous sodium sulphate and then stored in airtight and watertight glass containers at a low temperature $\left(-4{ }^{\circ} \mathrm{C}\right)$ until analysis.

\subsection{GC-FID and GC-MS Analyses of Essential Oils Extracted by Hydrodistillation \\ 2.3.1. Gas Chromatography-Flame Ionization Detector (GC-FID)}

Under the recorded experimental conditions [27,28], GC analysis of essential oils was performed on a Varian 450 gas chromatograph fitted with FID, using a ZB-5 stationary phase (30 $\mathrm{m} \times 0.25 \mathrm{~mm}$ i.d., $0.25 \mathrm{~m}$ film thickness) column. The temperature program was (60 to 220 ) ${ }^{\circ} \mathrm{C}$ at $3{ }^{\circ} \mathrm{C} / \mathrm{min}$; for the injector and detector, temperatures were 230 and $240{ }^{\circ} \mathrm{C}$, respectively. The injection volume was $1.0 \mu \mathrm{L}$ of $1 \%$ solution diluted in $n$-hexane, the split ratio was 1:50.

\subsubsection{Gas Chromatography-Mass Spectrometry (GC-MS)}

The critical oils were GC-MS analyzed using a Thermo Scientific Trace Ultra GC coupled to a Thermo Scientific ITQ 1100 Mass Spectrometer with a ZB-5 $(30 \mathrm{~m} \times 0.25 \mathrm{~mm}$ i.d.; $0.25 \mathrm{~m}$ film thicknesses) column. The oven temperature was programmed from 60-220 ${ }^{\circ} \mathrm{C}$ at $3{ }^{\circ} \mathrm{C} \mathrm{min}-1$ using helium as a carrier gas at $1 \mathrm{~mL} \mathrm{~min}^{-1}$. The injector temperature was $230^{\circ} \mathrm{C}$; the injection volume was $0.1 \mu \mathrm{L}$ of $1 \%$ solution prepared in $n$ hexane, split ratio 50:1. The mass spectrometry (MS) spectrum was taken at $70 \mathrm{eV}$ with a mass scan range of 40-450 amu. All of the experimental parameters were applied based on those reported earlier $[27,29,30]$.

\subsubsection{Identification of the Constituents}

The retention index values were used to assess the already listed constituents (RI, determined concerning homologous series of $n$-alkanes C8-C25, analyzed under identical experimental conditions), MS library quest (NIST 08 Mass Spectra Library (Version 2.0 f), and WILEY'S Library of Mass Spectra 9th Edition), MS literature data comparison [31], and co-injection of commercial samples from Sigma-Aldrich, India ( $\geq 98$ percent purity). The relative amount of individual components were calculated based on the GC peak area (FID response) without using a correction factor.

\section{Results and Discussion}

The hydrodistillation of samples of dried Pimpinella lutea aerial parts collected in separate bioclimatic zones (North Bizerta, South Bizerta, and Tabarka) afforded three yellowish essential oils, with yields of $0.49 \%, 0.46 \%$, and $0.41 \%$, respectively). Table 2 displays the findings of the initial chemical analysis of essential oils extracted from different Tunisian locations. The volatile oil's chemical composition was determined using GC-FID and GC-MS techniques. To increase the reliability of identification, the mass spectra and the calculated LRI were compared with those of the same substances computerized in the data bank. According to the resulting analysis, a total of 73 organic volatiles were identified: 39 from NBEO (North Bizerta location), 44 from SBEO (South Bizerta location), and 51 from 
TEO (Tabarka location), representing 76.2\%, 94.6\%, and $97.6 \%$ of the whole essential oil constituents, respectively. Despite some variations in chemotype structures depending on the environmental sources, common patterns in qualitative composition were established.

Pimpinella lutea essential oils consisted of monoterpenes and sesquiterpene hydrocarbons, oxygenated sesquiterpenes and phenyl derivatives, as shown in Figure 2.

A specific feature of Pimpinella lutea essential oil is the predominance of sesquiterpenes constituting the main groups in NBEO (72.2\%), SBEO (78.1\%), and TEO (60.2\%). Even though this fraction dominated in all volatile oils, some qualitative and quantitative chemogeographical variability was clear in all samples. In particular, the acorane sesquiterpenoid acora-3,7(14)-dien Figure 3 was quantified at a reasonably high concentration (29.1\%) in TEO but in a significantly lower amount in NBEO (3.4\%) and SBEO (4.7\%), respectively. Moreover, $\beta$-pinene ranked second in abundance for Pimpinella lutea collected in the sandy soil of Tabarka. At the same time, it occurred at a shallow mean content in SBEO (1.1\%) and was completely absent in the sample harvested in the calcareous marly soil (NBEO). It is worth mentioning that several studies have demonstrated the anti-cancer properties and the high activity of $\beta$-pinene against both Gram-positive and Gram-negative bacteria and Candida albicans yeast [32]. $\alpha$-trans-Bergamotene identified as the primary sesquiterpene metabolite in NBEO (18.1\%) was less observed in SBEO (6.4\%) and as a trace element in Tabarka's sample (1.5\%) (Table 2). In addition, It is interestingly noticeable that NBEO and SBEO were distinguished by almost equal amounts of muurola-4,10(14)-dien-1- $\beta$-ol ranging from $8.9 \%$ to $10.1 \%$ in both samples, respectively. In contrast, this compound was not detected in TEO. Fokienol, the second interesting odorant in SBEO (9.1\%) against a deficient level in NBEO, was utterly absent in TEO. As evidenced by previously published studies, this variation in terpene metabolites might be attributed to different climatic and edaphic conditions.

On reviewing the literature, several studies were performed on the chemical composition of essential oils extracted from Pimpinella anisum L. seeds, widely used as a culinary ingredient. The results revealed that in contrast to Pimpinella lutea (Desf.), Tunisian aniseeds contained noticeable amounts of phenylpropanoids (more than $95 \%$ ) and were primarily composed of trans anethole (94.3\%). However, P. anisum essential oil was very poor on sesquiterpenes hydrocarbons [33].

Table 2. The chemical profiles of essential oils extracted from Pimpinella lutea (Desf.) subspecies from various locations of Tunisia.

\begin{tabular}{|c|c|c|c|c|c|c|}
\hline \multirow{2}{*}{ No } & \multirow{2}{*}{ Compound } & \multirow{2}{*}{ RI } & \multirow{2}{*}{ AI } & \multicolumn{3}{|c|}{ Content (\%) } \\
\hline & & & & NBEO & SBEO & TEO \\
\hline 1 & $\alpha$-Thujene & 943 & 930 & - & 0.1 & 0.3 \\
\hline 2 & $\alpha$-pinene & 947 & 939 & $\operatorname{Tr}$ & 0.5 & 0.1 \\
\hline 3 & trans-Pinene & 968 & 975 & 0.5 & - & - \\
\hline 4 & Sabinene & 977 & 976 & 0.7 & - & - \\
\hline 5 & $\beta$-pinene & 981 & 980 & - & 1.1 & 18.2 \\
\hline 6 & Myrcene & 993 & 979 & - & - & 0.1 \\
\hline 7 & dehydro-1,8-Cineol & 995 & 991 & - & $\operatorname{Tr}$ & $\operatorname{tr}$ \\
\hline 8 & $\alpha$-Phellandrene & 1007 & 1002 & - & - & $\operatorname{tr}$ \\
\hline 9 & $\alpha$-Terpinene & 1018 & 1017 & - & 0.7 & 0.5 \\
\hline 10 & p-Cymene & 1026 & 1024 & 0.2 & $\operatorname{Tr}$ & 1.7 \\
\hline 11 & Limonene & 1030 & 1029 & 0.1 & 0.1 & 0.2 \\
\hline 12 & 1,8-Cineol & 1031 & 1031 & $\operatorname{Tr}$ & - & - \\
\hline 13 & $\gamma$-Terpinene & 1061 & 1059 & - & 0.3 & 0.4 \\
\hline 14 & Cis-Sabinene hydrate & 1070 & 1070 & - & 0.2 & 0.9 \\
\hline 15 & m-Cresol & 1080 & 1076 & 0.8 & - & 0.5 \\
\hline 16 & Terpinolene & 1093 & 1088 & - & 0.1 & 0.3 \\
\hline 17 & Linalool & 1104 & 1096 & 0.1 & 0.5 & 0.8 \\
\hline
\end{tabular}


Table 2. Cont.

\begin{tabular}{|c|c|c|c|c|c|c|}
\hline \multirow{2}{*}{ No } & \multirow{2}{*}{ Compound } & \multirow{2}{*}{ RI } & \multirow{2}{*}{ AI } & \multicolumn{3}{|c|}{ Content $(\%)$} \\
\hline & & & & NBEO & SBEO & TEO \\
\hline 18 & cis-p-Menth-2-en-1-ol & 1130 & 1121 & - & 0.9 & 0.5 \\
\hline 19 & trans-p-Menth-2-en-1-ol & 1151 & 1140 & - & 0.5 & 1.1 \\
\hline 20 & Geijerene & 1153 & 1143 & 0.9 & - & $\operatorname{tr}$ \\
\hline 21 & (Z)-Tagetone & 1163 & 1152 & - & - & 0.3 \\
\hline 22 & Sabina ketone & 1173 & 1159 & - & 0.9 & 0.6 \\
\hline 23 & Menthofuran & 1176 & 1164 & 0.1 & - & 0.1 \\
\hline 24 & Terpin-4-ol & 1197 & 1177 & 0.1 & 1.9 & 5.9 \\
\hline 25 & $p$-Cymen-8-ol & 1205 & 1182 & - & 0.6 & 1.2 \\
\hline 26 & $\alpha$-Terpineol & 1212 & 1188 & - & $\operatorname{Tr}$ & 0.2 \\
\hline 27 & Myrtenal & 1215 & 1195 & - & 0.3 & - \\
\hline 28 & cis-Piperitol & 1217 & 1196 & - & - & 0.3 \\
\hline 29 & trans-Piperitol & 1232 & 1208 & - & 0.3 & 0.7 \\
\hline 30 & cis-Sabinene hydrate acetate & 1244 & 1221 & 0.5 & - & 0.1 \\
\hline 31 & Coahuilensol, methyl ether & 1269 & 1221 & - & - & 0.5 \\
\hline 32 & trans-Sabinene hydrate acetate & 1285 & 1256 & - & - & 0.1 \\
\hline 33 & $(E)$-Anethole & 1326 & 1284 & - & 0.5 & 0.4 \\
\hline 34 & Pregeijerene & 1330 & 1287 & - & - & 0.5 \\
\hline 35 & p-Cymene-7-ol & 1332 & 1290 & - & 0.9 & 0.8 \\
\hline 36 & Carvacrol & 1346 & 1299 & 0.1 & 6.1 & 0.1 \\
\hline 37 & $\delta$-Elemene & 1388 & 1338 & 0.2 & 0.7 & - \\
\hline 38 & Piperitenone & 1391 & 1343 & $\operatorname{Tr}$ & - & - \\
\hline 39 & $\alpha$-Cubebene & 1402 & 1351 & $\operatorname{Tr}$ & 0.5 & 0.6 \\
\hline 40 & $\alpha$-Copaene & 1434 & 1376 & 0.5 & 0.8 & 0.2 \\
\hline 41 & Daucene & 1437 & 1381 & - & 0.3 & - \\
\hline 42 & $\beta$-Cubenene & 1451 & 1388 & - & - & $\operatorname{tr}$ \\
\hline 43 & Acora-3,7(14)-dien & 1478 & 1408 & 3.4 & 4.7 & 29.1 \\
\hline 44 & $\beta$-Cedrene & 1490 & 1420 & 8.9 & 0.2 & 0.6 \\
\hline 45 & $\alpha$-trans-Bergamotene & 1502 & 1433 & 18.1 & 6.4 & 1.5 \\
\hline 46 & $\alpha$-Humulene & 1525 & 1452 & - & - & 0.7 \\
\hline 47 & (E)- $\beta$-Farnesene & 1529 & 1456 & 0.3 & 0.9 & 0.5 \\
\hline 48 & cis-Muurola-4(14),5-diene & 1544 & 1466 & 3.1 & 1.3 & 0.2 \\
\hline 49 & Germacrene D & 1555 & 1480 & - & - & 5.9 \\
\hline 50 & ar-Curcumene & 1556 & 1483 & 0.7 & - & - \\
\hline 51 & $\beta$-Selinene & 1564 & 1490 & - & - & 6.5 \\
\hline 52 & $\alpha$-Selinene & 1573 & 1492 & - & - & 4.1 \\
\hline 53 & $\alpha$-Alaskene & 1593 & 1512 & 1.0 & 4.7 & 1.6 \\
\hline 54 & cis-Calamene & 1601 & 1522 & 6.1 & 4.5 & - \\
\hline 55 & $\delta$-Cadinene & 1604 & 1523 & - & - & 0.8 \\
\hline 56 & trans-Calamene & 1615 & 1529 & 3.1 & 3.2 & 0.6 \\
\hline 57 & $\alpha$-Calacorene & 1626 & 1545 & 1.5 & - & - \\
\hline 58 & cis-Cadinene ether & 1638 & 1553 & - & - & 0.5 \\
\hline 59 & Elemicin & 1639 & 1557 & $\operatorname{Tr}$ & - & - \\
\hline 60 & trans-Cadinene ether & 1647 & 1558 & - & 2.5 & 0.9 \\
\hline 61 & Spathulenol & 1664 & 1578 & 1.2 & 5.9 & - \\
\hline 62 & Fokienol & 1687 & 1596 & 0.5 & 9.1 & - \\
\hline 63 & $\beta$-Atlantol & 1696 & 1608 & 1.3 & 5.6 & - \\
\hline 64 & 2-epi- $\alpha$-Cedren-3-one & 1710 & 1627 & - & 5.5 & - \\
\hline 65 & Muurola-4,10(14)-dien-1- $\beta$-ol & 1719 & 1631 & 8.9 & 10.1 & - \\
\hline 66 & Cedr-8(15)-en-9- $\alpha$-ol & 1743 & 1651 & 2.5 & 1.0 & - \\
\hline 67 & epi-Zizanone & 1768 & 1670 & 6.5 & 7.5 & - \\
\hline 68 & $\alpha$-Bisabolol & 1778 & 1685 & 1.4 & - & - \\
\hline 69 & epi-Nootkatol & 1784 & 1699 & 0.8 & 1.5 & - \\
\hline 70 & 10-nor-Calamenene-10-one & 1806 & 1702 & 0.3 & - & - \\
\hline 71 & (Z)- $\alpha$-Atlantone & 1810 & 1718 & 1.0 & 1.2 & - \\
\hline 72 & Zerumbone & 1819 & 1733 & 0.8 & - & 5.6 \\
\hline 73 & Cyclocolorenone & 1844 & 1760 & - & - & 0.3 \\
\hline
\end{tabular}


Table 2. Cont.

\begin{tabular}{|c|c|c|c|c|c|c|}
\hline \multirow{2}{*}{ No } & \multirow{2}{*}{ Compound } & \multirow{2}{*}{ RI } & \multirow{2}{*}{ AI } & \multicolumn{3}{|c|}{ Content (\%) } \\
\hline & & & & NBEO & SBEO & TEO \\
\hline & Oxygenated Monoterpenes & & & 0.7 & 6.1 & 12.7 \\
\hline & Sesquiterpene Hydrocarbons & & & 46.9 & 28.2 & 52.9 \\
\hline & Oxygenated Sesquiterpenes & & & 25.2 & 49.9 & 7.3 \\
\hline & monoterpene Hydrocarbons & & & 1.5 & 2.9 & 21.8 \\
\hline & Phenyl derivatives & & & 1.9 & 7.5 & 2.9 \\
\hline & Total identified & & & 76.2 & 94.6 & 97.6 \\
\hline
\end{tabular}

RI: experimentally determined retention indices by co-injection of a homologous series of $n$-alkanes $C_{8}-C_{25}$ on a ZB5-MS fused silica column, AI: Adams retention indices, tr: trace and (-) not detected. OM: Oxygenated monoterpene, $\mathrm{SH}$ : Sesquiterpene hydrocarbon, $\mathrm{MH}$ : Monoterpene hydrocarbon, OS: Oxygenated sesquiterpene, PD: Phenyl derivative.

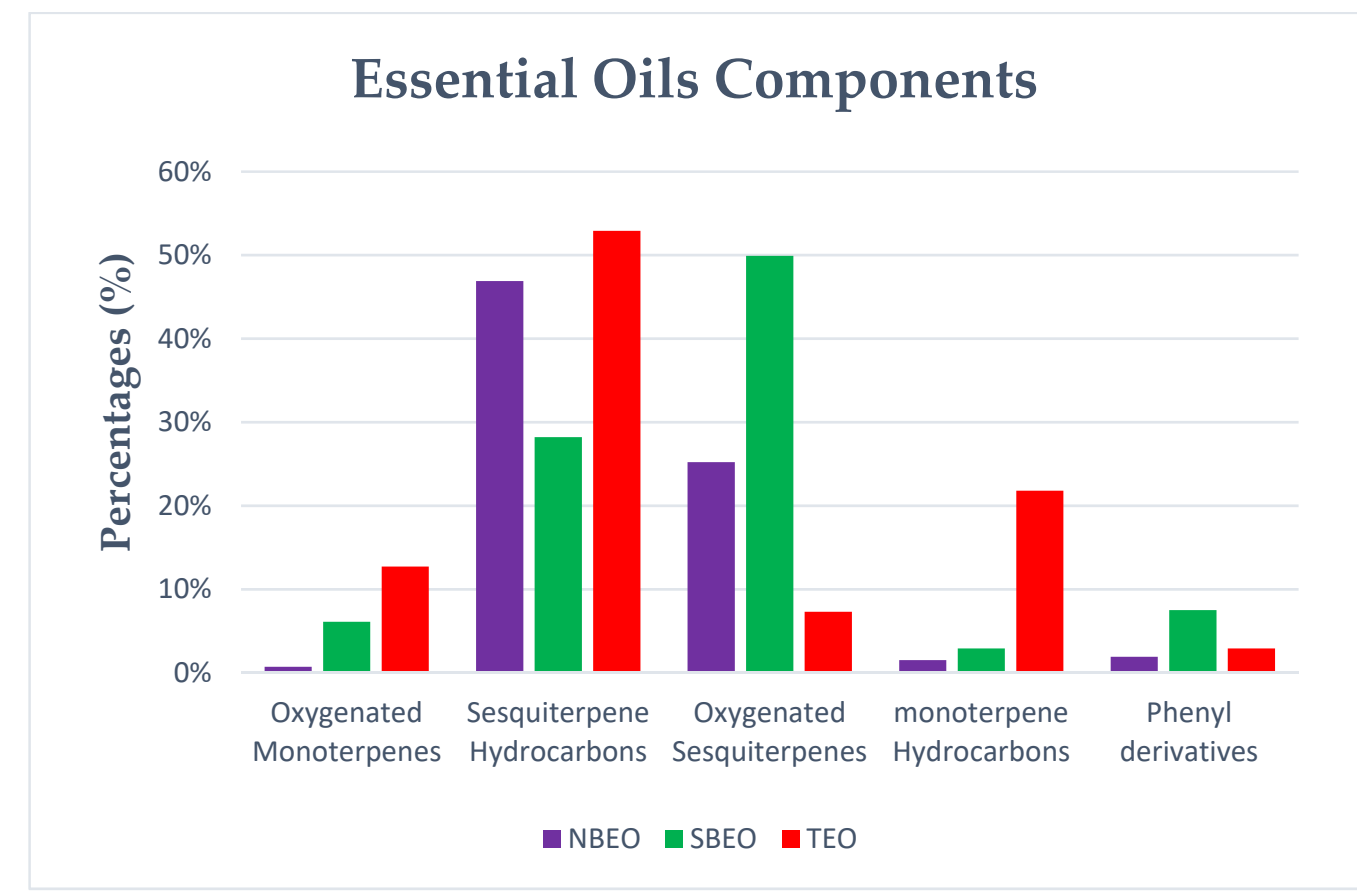

Figure 2. The semi-quantitative distribution of the main classes of organic volatiles in Pimpinella lutea growing in three different environmental conditions (North and South Bizerta and Tabarka) of Tunisia.
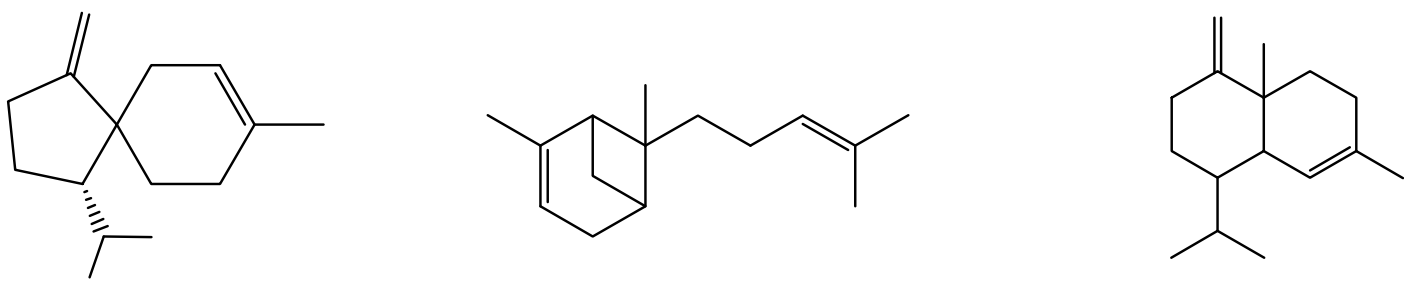

Acora-3,7(14)-dien (29.1\% in TEO)

$\alpha$-trans-Bergamotene (18.1\% in NBEO) $\quad$ Muurola-4,10(14)-dien-1- $\beta$-ol (10.1\% in SBEO)

Figure 3. The major organic volatiles of essential oils from Pimpinella lutea (Desf.). growing in three different environmental conditions (North and South Bizerta and Tabarka) of Tunisia.

\section{Conclusions}

The present work constitutes a first comparison of the chemical characteristics of essential oils produced by Pimpinella lutea growing wild in three Tunisian sites (North and South Bizerta and Tabarka). Regardless of the subspecies' type oil similarity, some qualitative and quantitative variations have been noticed due to several factors, including climatic, edaphic, or altitude. The overall results demonstrated the predominance of 
sesquiterpenes in all studied samples. The use of sesquiterpenes can help patients with squamous cell carcinoma of the esophagus have a better prognosis. Furthermore, it has the potential to reduce the adverse effects of chemoradiotherapy [34]. Thus, this analysis suggests that Pimpinella lutea essential oils have the potential to be used for pharmaceutical and commercial purposes and may supply market demands.

Author Contributions: Conceptualization, H.A.-H.; R.E.M.; R.K.J.; M.L.A. and S.H. methodology, R.K.J.; software, R.K.J. and S.H.; validation, R.K.J., M.L.A. and S.H.; formal analysis, R.K.J.; M.L.A. and S.H.; investigation, H.A.-H. and S.H.; resources, R.K.J. and S.H.; data curation, H.A.-H.; R.E.M.; R.K.J.; M.L.A. and S.H. writing-original draft preparation, R.K.J.; M.L.A. and S.H.; writing-review and editing, R.K.J. and S.H.; supervision, S.H. All authors have read and agreed to the published version of the manuscript.

Funding: This research received no external funding.

Institutional Review Board Statement: Not applicable.

Informed Consent Statement: Not applicable.

Acknowledgments: The authors are grateful to the Director of the ICMR-National Institute of Traditional medicine for instrumental facilities to analyze the chemical constituents.

Conflicts of Interest: The authors declare no conflict of interest.

\section{References}

1. Türk, D.; Hall, M.D.; Chu, B.F.; Ludwig, J.A.; Fales, H.M.; Gottesman, M.M.; Szakács, G. Identification of Compounds Selectively Killing Multidrug-Resistant Cancer Cells. Cancer Res. 2009, 69, 8293-8301. [CrossRef] [PubMed]

2. Pavela, R.; Maggi, F.; Iannarelli, R.; Benelli, G. Plant extracts for developing mosquito larvicides: From laboratory to the field, with insights on the modes of action. Acta Trop. 2019, 193, 236-271. [CrossRef] [PubMed]

3. Benellia, G.; Pavelab, R.; Zorzettoc, C.; Sánchez-Mateoc, C.C.; Santinid, G.; Canalea, A.; Maggid, F. Insecticidal activity of the essential oil from Schizogyne sericea (Asteraceae) on four insect pests and two non-target species. Èntomol. Gen. 2019, 39, 9-18. [CrossRef]

4. Raskin, I.; Ribnicky, D.M.; Komarnytsky, S.; Ilic, N.; Poulev, A.; Borisjuk, N.; Brinker, A.; Moreno, D.A.; Ripoll, C.; Yakoby, N.; et al. Plants and human health in the twenty-first century. Trends Biotechnol. 2002, 20, 522-531. [CrossRef]

5. Bakkali, F.; Averbeck, S.; Averbeck, D.; Idaomar, M. Biological effects of essential oils-A review. Food Chem. Toxicol. 2008, 46, 446-475. [CrossRef]

6. Hammami, S.; Jmii, H.; El Mokni, R.; Khmiri, A.; Faidi, K.; Dhaouadi, H.; El Aouni, M.H.; Aouni, M.; Joshi, R.K. Essential Oil Composition, Antioxidant, Cytotoxic and Antiviral Activities of Teucrium pseudochamaepitys Growing Spontaneously in Tunisia. Molecules 2015, 20, 20426-20433. [CrossRef]

7. Snene, A.; El Mokni, R.; Jmii, H.; Jlassi, I.; Jaïdane, H.; Falconieri, D.; Piras, A.; Dhaouadi, H.; Porcedda, S.; Hammami, S. In vitro antimicrobial, antioxidant and antiviral activities of the essential oil and various extracts of wild (Daucus virgatus (Poir.) Maire) from Tunisia. Ind. Crop. Prod. 2017, 109, 109-115. [CrossRef]

8. Riahi, L.; Elferchichi, M.; Ghazghazi, H.; Jebali, J.; Ziadi, S.; Aouadhi, C.; Chograni, H.; Zaouali, Y.; Zoghlami, N.; Mliki, A. Phytochemistry, antioxidant and antimicrobial activities of the essential oils of Mentha rotundifolia L. in Tunisia. Ind. Crop. Prod. 2013, 49, 883-889. [CrossRef]

9. Debbabi, H.; El Mokni, R.; Jlassi, I.; Falconieri, D.; Piras, A.; Mastouri, M.; Porcedda, S.; Hammami, S. Gas chromatography combined with mass spectrometry and flame ionization detection for identifying the organic volatiles from Stachys arvensis, $\mathrm{S}$. marrubiifolia and S. ocymastrum. Int. J. Mass Spectrom. 2018, 432, 59-64. [CrossRef]

10. Tripathi, P.; Dubey, N. Exploitation of natural products as an alternative strategy to control postharvest fungal rotting of fruit and vegetables. Postharvest Biol. Technol. 2004, 32, 235-245. [CrossRef]

11. Mittal, R.P.; Rana, A.; Jaitak, V. Essential Oils: An Impending Substitute of Synthetic Antimicrobial Agents to Overcome Antimicrobial Resistance. Curr. Drug Targets 2019, 20, 605-624. [CrossRef]

12. Delfine, S.; Marrelli, M.; Conforti, F.; Formisano, C.; Rigano, D.; Menichini, F.; Senatore, F. Variation of Malva sylvestris essential oil yield, chemical composition and biological activity in response to different environments across Southern Italy. Ind. Crop. Prod. 2017, 98, 29-37. [CrossRef]

13. Girardi, F.M.; Barra, M.B.; Zettler, C.G. Papillary thyroid carcinoma: Does the association with Hashimoto's thyroiditis affect the clinicopathological characteristics of the disease? Braz. J. Otorhinolaryngol. 2015, 81, 283-287. [CrossRef]

14. Ben Farhat, M.; Sotomayor, J.A.; Jordán, M.J. Salvia verbenaca L. essential oil: Variation of yield and composition according to collection site and phenophase. Biochem. Syst. Ecol. 2019, 82, 35-43. [CrossRef]

15. Cassel, E.; Vargas, R.M.F. Experiments and modeling of the Cymbopogonwinterianus essential oil extraction by steam distilla-tion. J. Mexican Chem. Soc. 2006, 50, 126-129. 
16. Lira, P.D.L.; Retta, D.; Tkacik, E.; Ringuelet, J.; Coussio, J.; van Baren, C.M.; Bandoni, A. Essential oil and by-products of distillation of bay leaves (Laurus nobilis L.) from Argentina. Ind. Crop. Prod. 2009, 30, 259-264. [CrossRef]

17. Hunter, M. Essential Oils: Art, Agriculture, Science, Industry and Entrepreneurship: (A Focus on the Asia-Pacific Region); Nova Science Publishers, Inc.: Hauppauge, NY, USA, 2009; pp. 179-180.

18. Burt, S. Essential oils: Their antibacterial properties and potential applications in foods-A review. Int. J. Food Microbiol. 2004, 94, 223-253. [CrossRef]

19. Şanli, A.; Karadoğan, T. Geographical Impact on Essential Oil Composition of Endemickundmannia Anatolica HUB.-Mor. (Apiaceae). Afr. J. Tradit. Complement. Altern. Med. 2016, 14, 131-137. [CrossRef]

20. Lim, X.Y.; Teh, B.P.; Tan, T.Y.C. Medicinal Plants in COVID-19: Potential and Limitations. Front. Pharmacol. 2021, $12,611408$. [CrossRef]

21. Christensen, L.P.; Brandt, K. Bioactive polyacetylenes in food plants of the Apiaceae family: Occurrence, bioactivity and analysis. J. Pharm. Biomed. Anal. 2006, 41, 683-693. [CrossRef]

22. Downie, S.R.; Katz-Downie, D.S.; Spalik, K. A phylogeny of Apiaceae tribe Scandiceae: Evidence from nuclear ribosomal DNA internal transcribed spacer sequences. Am. J. Bot. 2000, 87, 76-95. [CrossRef] [PubMed]

23. Pottier-Alapetite, G. Flore de la Tunisie: Angiospermes-Dicotylédones. Apétales-Dialypétales; Ministère de l'Enseignement Supé-rieur et de la Recherche Scientifique \& Ministère de l'Agriculture: Tunis, Tunisia, 1979; p. 651.

24. Makhloufi, E.; Akkal, S.; Medjroubi, K.; Elomri, A.; Laouer, H.; Verité, P.; Seguin, E. Chemical constituents of the extract Algerian Reutera lutea (Desf.) Maire, (Apiaceae). Pharmacogn. Commun. 2013, 3, 41-44.

25. Djeddi, N.; Benahmed, M.; Akkal, S.; Laouer, H.; Makhloufi, E.; Gherraf, N. Study on methylene dichloride and butanolic extracts of Reutera lutea (Desf.) Maire (Apiaceae) as effective corrosion inhibitions for carbon steel in $\mathrm{HCl}$ solution. Res. Chem. Intermed. 2014, 41, 4595-4616. [CrossRef]

26. Wang, Y.-H.; Zhang, Y.-R. Variations in compositions and antioxidant activities of essential oils from leaves of Luodian Blumea balsamifera from different harvest times in China. PLoS ONE 2020, 15, e0234661. [CrossRef]

27. Joshi, R.K. Terpenoids of Blumea oxyodonta Essential Oil. Chem. Nat. Compd. 2018, 54, 377-379. [CrossRef]

28. Joshi, R.K. Chemical Composition of Leucas Stelligera. Chem. Nat. Compd. 2015, 51, 579-580. [CrossRef]

29. Joshi, R.K. GC-MS analysis of the volatile constituents of Orthosiphon pallidus Royle, ex Benth. Nat. Prod. Res. 2019, 34, 441-444. [CrossRef]

30. Joshi, R.K. GC/MS Analysis of the Essential Oil of Vernonia cinerea. Nat. Prod. Commun. 2015, 10, 1319-1320. [CrossRef]

31. Adams, R.P. Identification of Essential Oil Components by Gas Chromatography/Mass Spectrometry, 4th ed.; Allured Pub Corp.: Carol Stream, IL, USA, 2007.

32. Salehi, B.; Upadhyay, S.; Orhan, I.E.; Jugran, A.K.; Jayaweera, S.L.; Dias, D.A.; Sharopov, F.; Taheri, Y.; Martins, N.; Baghalpour, N.; et al. Therapeutic Potential of $\alpha$ - and $\beta$-Pinene: A Miracle Gift of Nature. Biomolecules 2019, 9, 738. [CrossRef]

33. Rebey, I.B.; Bourgou, S.; Wannes, W.A.; Selami, I.H.; Tounsi, M.S.; Marzouk, B.; Fauconnier, M.L.; Ksouri, R. Comparative assessment of phytochemical profiles and antioxidant properties of Tunisian and Egyptian anise (Pimpinella anisum L.) seeds. Plant Biosyst. Int. J. Deal. All Asp. Plant Biol. 2017, 152, 971-978. [CrossRef]

34. Franco, C.; Ferreira, O.; de Moraes, Â.A.B.; Varela, E.; Nascimento, L.; Percário, S.; de Oliveira, M.; Andrade, E. Chemical Composition and Antioxidant Activity of Essential Oils from Eugenia patrisii Vahl, E. punicifolia (Kunth) DC., and Myrcia tomentosa (Aubl.) DC., Leaf of Family Myrtaceae. Molecules 2021, 26, 3292. [CrossRef] 